\title{
PREFERENSI KONSUMEN BERAS DI PASAR KRIAN KABUPATEN SIDOARJO
}

\author{
Syarif Imam Hidayat ${ }^{*}$, Silvy Emalia Savitri ${ }^{1}$ \\ Program Studi Agribisnis Universitas Pembangunan Nasional "Veteran" Jawa Timur. \\ e-mail: syarifimamhidayat@yahoo.com
}

\begin{abstract}
Preference is subjective taste of individual for product or service. Preference becomes one of the determinant factors for consumption level of a product, includes rice. Rice consumption level is also impacted by difference in the level of consumer income. This study aims to analyze the preferences of rice consumers at Krian Market, Sidoarjo Regency. This study was conducted at Krian Market, Sidoarjo Regency, using a method of non-probability sampling through accidental sampling by 50 respondents. The analysis tool was Importance Performance Analysis (IPA). The result showed that the highest score of importance level is flea pests-free, clean, and fluffier. It means that rice consumer preferences at Krian Market where rice that flea pests-free, clean, and fluffier.
\end{abstract}

Key words: Preferences and Rice Consumer.

\section{PENDAHULUAN}

Bagi Indonesia, pangan sering diidentikkan dengan beras karena jenis pangan ini merupakan makanan pokok utama. Riyadi (2002) mengemukakan bahwa 98\% penduduk Indonesia mengonsumsi beras sebagai makanan pokok. Peran beras sebagai makanan pokok di Indonesia sampai saat ini sulit disubstitusikan dengan jenis makanan pokok yang lain. Bahkan ketergantungan terhadap komoditi beras dapat dilihat melalui jumlah konsumsi beras per kapita di Indonesia tercatat hampir 112 kilogram (beras, per orang, per tahun) pada tahun 2017. Tingkat konsumsi ini melebihi tingkat konsumsi beras dunia yang berkisar 80 sampai dengan $90 \mathrm{~kg} / \mathrm{kapita} /$ tahun. Tingginya konsumsi beras di Indonesia juga dikarenakan adanya budaya makan yang dimiliki rakyat Indonesia yang merasa belum makan jika belum mengonsumsi nasi, meskipun kebutuhan karbohidratnya sudah dipenuhi dari makanan lain.

Provinsi Jawa Timur dikenal sebagai salah satu lumbung padi nasional, memproduksi padi Jawa Timur sebesar 13.06 juta ton dengan luas lahan 2.136.412 Ha pada ada tahun 2017 (Badan Pusat Statistik, 2018). Kabupaten Sidoarjo merupakan daerah penyangga ibukota Jawa Timur. Kabupaten Sidoarjo memiliki struktur masyarakat yang beraneka ragam. Keragaman tersebut meliputi budaya, gaya hidup, pendidikan dan pekerjaan, serta tingkat perekonomian yang tercermin dalam kehidupan seharihari. Keragaman yang tercipta tentu mempengaruhi masyarakat di Kabupaten Sidoarjo dalam preferensi dari suatu produk, termasuk mengonsumsi beras.

Kecamatan Krian yang menjadi salah satu kecamatan dengan perekonomian cukup baik di Kabupaten Sidoarjo memiliki Pasar Krian sebagai penggerak perekonomian. Pasar Krian menyediakan berbagai macam kebutuhan pokok, termasuk beras. Dari 17 kios dan agen beras, sebanyak $82 \%$ atau 14 penjual beras menyatakan bahwa beras yang jarang dibeli oleh konsumen adalah jenis Pandan Wangi 
dan beras yang paling sering dibeli adalah IR 64 dan Bramo. Jenis beras Pandan Wangi harganya lebih mahal dibandingkan jenis beras lainnya, namun beras Pandan Wangi dikenal sangat pulen dan harum.

Dalam ekonomi, harga produk (termasuk harga gabah dan beras) mempunyai peran sangat penting karena mempertemukan kepentingan produsen dan konsumen. Setiap produsen tentu memiliki harapan yang sama. Produsen mengharapkan beras yang telah diproduksi akan laku terjual dengan harga yang tinggi dan memiliki banyak pelanggan. Sehingga, produsen dapat memiliki bisnis yang menguntungkan. Selain itu, produsen juga berharap agar dapat menyediakan beras yang diproduksi sesuai dengan kebutuhan dan keinginan konsumen.

Di sisi lain, harapan konsumen terhadap beras yang dibeli juga bervariasi. Konsumen tentu ingin mengonsumsi beras dengan bentuk yang utuh, tidak pecah, rasa pulen, berwarna putih di dalam kemasan yang baik. Namun, konsumen juga ingin harga yang rendah tapi mendapatkan beras berkualitas yang selalu tersedia dalam jumlah yang cukup di pasar, sehingga mudah didapatkan. Hal ini tentu menjadi pertimbangan konsumen dalam membeli beras. Berdasarkan permasalahan di atas, penelitian ini bertujuan untuk menganalisis preferensi konsumen beras di Pasar Krian, Kabupaten Sidoarjo.

\section{Asumsi Penelitian}

a. Setiap rumah tangga membutuhkan beras sebagai pangan pokok utama.

b. Beras tersedia dalam jumlah yang banyak dan beragam, dalam kualitas dan merek dagangnya.

c. Tidak ada gejolak harga yang ekstrem dan kelangkaan persediaan harga beras di pasar.

d. Responden mudah mengetahui dan mengenali jenis maupun kualitas beras.

e. Faktor-faktor lain di luar variabel penelitian ini dianggap dalam kondisi normal, sama, dan tidak ada perubahan

\section{METODE PENELITIAN}

Lokasi penelitian dilakukan pada Pasar Krian yang berlokasi di Jalan Dr. Setiabudi, Krian, Kecamatan Krian, Kabupaten Sidoarjo. Pemilihan lokasi dilakukan secara sengaja (purposive) dengan pertimbangan bahwa Pasar Krian merupakan salah satu pasar terbesar di Kabupaten Sidoarjo dengan jenis dan varietas beras beragam, baik curah maupun berlabel yang datang dari daerah Krian dan berbagai daerah lainnya, seperti Pacet, Trawas, Mojokerto, Gresik, Jombang, dan Sidoarjo.

\section{Penentuan Sampel}

Populasi dalam penelitian ini adalah konsumen yang membeli beras di Pasar Krian, Kabupaten Sidoarjo. Metode penentuan sampel yang akan digunakan dalam penelitian ini adalah metode non probability sampling, karena jumlah populasi yang diteliti tidak diketahui atau tidak pasti. Jumlah sampel dalam penelitian ini ditentukan berjumlah 50 sampel dan dibagi dalam dua katogori yaitu konsumen berjenis kelamin perempuan berstatus menjadi ibu rumah tangga yang sudah sering membeli dan mengonsumsi beras dengan pertimbangan ibu adalah seseorang yang merencanakan, membelanjakan, dan ikut mengonsumsi beras. Sedangkan katogori lainnya adalah konsumen yang membeli beras di Pasar Krian, Kabupaten Sidoarjo

\section{Pengumpulan Data}

Data yang digunakan pada penelitian ini yaitu data primer dan data sekunder. Data primer diperoleh melalui kuesioner, wawancara dan dokumentasi langsung pada konsumen dan pedagang beras di Pasar Krian. Sedangkan, untuk data sekunder diperoleh melalui media internet, seperti data di Badan Pusat Statistik, buku, internet, dan studi literatur lain yang telah terbukti kebenarannya. 


\section{Definisi Operasional}

a. Preferensi konsumen merupakan selera konsumen atau tingkat kesukaan konsumen yang diukur dengan kegunaan dari atribut beras yang dikonsumsi.

b. Beras merupakan bahan pangan pokok utama dalam rumah tangga yang berasal dari bulir padi yang telah dipisah dari sekam.

c. Analisis IPA (Important and Perfomance Analysis) merupakan alat bantu untuk menganalisis bagaimana preferensi konsumen terhadap beras di Pasar Krian melalui tingkat kepentingan dan tingkat kinerja dari atribut beras.

\section{Analisis Data}

Data-data yang telah diperoleh melalui penyebaran kuesioner dianalisis dangan analisis Importance and Performance Analysis (IPA). Analisis ini mengaitkan antara tingkat kepentingan (importance) suatu atribut yang dimiliki oleh suatu produk tertentu dengan kenyataan (performance) yang dirasakan oleh konsumen. Tingkat kepentingan adalah seberapa penting suatu atribut bagi pelanggan. Sedangkan tingkat kinerja adalah kinerja aktual dari atribut yang dirasakan oleh konsumen. Tingkat kinerja ini erat kaitannya dengan penilaian konsumen.

Importance and Perfomance Index (IPA) digunakan untuk menganalisis bagaimana preferensi konsumen terhadap atribut beras yang membeli di Pasar Krian, Kabupaten Sidoarjo. Langkah-langkah analisis Importance and Perfomance Index (IPA) adalah (Supranto, 2006) :

1. Menentukan tingkat kepentingan dan kinerja dari atribut beras dengan pengisian kuesioner oleh responden. Tingkat kepentingan dan kinerja dalam penelitian ini menggunakan 4 tingkat skala Likert, dimodelkan dalam Tabel 3.2 berikut ini.

Tabel 1. Skala Likert Untuk Tingkat Kepentingan dan Tingkat Kinerja

\begin{tabular}{ccc}
\hline Skor & Kepentingan & Kinerja \\
\hline 1 & Tidak Penting & Tidak Baik \\
2 & Kurang Penting & Kurang Baik \\
3 & Penting & Baik \\
4 & Sangat Penting & Sangat Baik \\
\hline
\end{tabular}

2. Menghitung rata-rata tingkat kepentingan dan tingkat kepuasan untuk setiap item dari atribut. Dalam analisis data ini terdapat dua buah variabel yang diwakili oleh huruf $\mathrm{X}$ dan $\mathrm{Y}$, dimana $\mathrm{X}$ menunjukkan tingkat kinerja suatu produk, sementara $\mathrm{Y}$ menunjukkan tingkat kepentingan konsumen.

Rumus : $\overline{\mathrm{X}}=\frac{\sum \mathrm{Xi}}{n}$ dan $\overline{\mathrm{Y}}=\frac{\sum \mathrm{Yi}}{n}$

Keterangan :

$\overline{\mathrm{X}}=$ skor rata-rata tingkat kinerja

$\mathrm{Xi}=$ skor rata-rata tingkat kinerja atribut ke- $\mathrm{i}$ 
$\bar{Y}=$ skor rata-rata tingkat kepentingan

$\mathrm{Yi}=$ skor rata-rata tingkat kepentingan atribut ke-i

$\mathrm{n}=$ jumlah responden

3. Menghitung nilai rata-rata tingkat kepentingan dan tingkat kepuasan untuk keseluruhan atribut.

Nilai rata - rata tersebut digunakan sebagai batas dalam diagram kartesius.

Rumus : $a=\frac{\sum \overline{\mathrm{Xi}}}{k}$ dan $b=\frac{\sum \overline{\mathrm{Yi}}}{k}$

Keterangan :

$a=$ nilai rata-rata tingkat kinerja seluruh atribut

$b=$ nilai rata-rata tingkat kepentingan seluruh atribut

$\mathrm{k}=$ jumlah atribut yang digunakan

4. Menentukan letak batas dua garis berpotongan tegak pada sumbu X dengan nilai rata-rata dari rata skor kinerja dari dan sumbu Y dengan nilai rata-rata dari rata skor kepentingan pada diagram Cartesius.

5. Membuat diagram Cartesius dengan menjabarkan tiap atribut sumbu $X$ (kinerja) dan sumbu $Y$ (kepentingan) dengan menempatkan nilai rata-rata atribut sebagai garis tengah

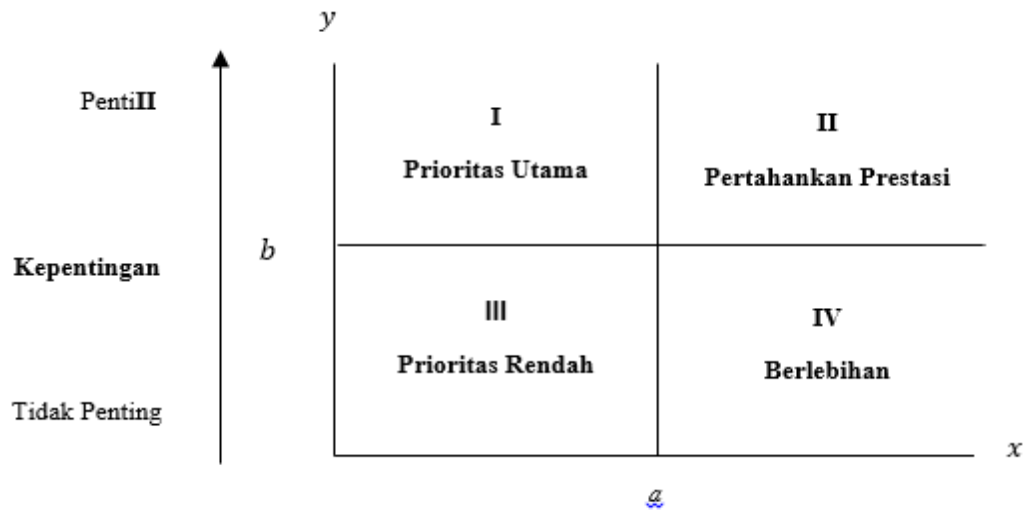

Sumber : Supranto, 2006

Gambar 1. Diagram Kartesius (Important and Performance Analisys) 


\section{HASIL DAN PEMBAHASAN}

Berikut disajikan hasil perhitungan tingkat kepentingan dan tingkat kinerja atribut beras menggunakan analisis IPA (Importance and Perfomance Analysis).

Tabel 2. Hasil Perhitungan Importance and Perfomance Analysis (IPA)

\begin{tabular}{|c|c|c|c|c|c|}
\hline \multirow{2}{*}{ No. } & \multirow{2}{*}{ Atribut Beras } & \multicolumn{2}{|c|}{ Tingkat Kepentingan } & \multicolumn{2}{|c|}{ Tingkat Kinerja } \\
\hline & & $\sum \mathrm{Yi}$ & $\overline{\mathrm{Y}}$ & $\sum \mathrm{Xi}$ & $\bar{X}$ \\
\hline 1 & Bentuk beras & 159 & 3.18 & 152 & 3.04 \\
\hline 2 & Warna alami (putih) & 156 & 3.12 & 155 & 3.1 \\
\hline 3 & Keutuhan beras & 152 & 3.04 & 156 & 3.12 \\
\hline 4 & Beras pecah & 138 & 2.76 & 153 & 3.06 \\
\hline 5 & $\begin{array}{l}\text { Bersih dari benda selain } \\
\text { beras }\end{array}$ & 168 & 3.36 & 158 & 3.16 \\
\hline 6 & Kepulenan & 168 & 3.36 & 154 & 3.08 \\
\hline 7 & Aroma nasi & 158 & 3.16 & 151 & 3.02 \\
\hline 8 & $\begin{array}{l}\text { Daya tahan beras untuk } \\
\text { disimpan }\end{array}$ & 163 & 3.26 & 156 & 3.12 \\
\hline 9 & Hama kutu & 175 & 3.5 & 175 & 3.5 \\
\hline 10 & Jenis / varietas beras & 150 & 3 & 135 & 2.7 \\
\hline 11 & Kemasan memiliki merek & 157 & 3.14 & 149 & 2.98 \\
\hline 12 & Plastic $5 \mathrm{~kg}$ & 133 & 2.66 & 149 & 2.98 \\
\hline 13 & Karung $10 \mathrm{~kg}$ & 125 & 2.5 & 135 & 2.7 \\
\hline 14 & Karung $>10 \mathrm{~kg}$ & 136 & 2.72 & 143 & 2.86 \\
\hline 15 & Beras tanpa kemasan & 126 & 2.52 & 122 & 2.44 \\
\hline 16 & Kemudahan diolah & 161 & 3.22 & 159 & 3.18 \\
\hline 17 & Mudah mendapatkan beras & 149 & 2.98 & 166 & 3.32 \\
\hline 18 & Harga beras & 163 & 3.26 & 172 & 3.44 \\
\hline 19 & Mengenyangkan & 165 & 3.3 & 158 & 3.16 \\
\hline \multirow[t]{3}{*}{20} & Kebiasaan mengonsumsi & 166 & 3.32 & 166 & 3.32 \\
\hline & Total & 3068 & 61.36 & 3064 & 61.28 \\
\hline & Rata - Rata & & 3.068 & & 3.064 \\
\hline
\end{tabular}

Sumber : Data Primer, Diolah (2020)

Hasil perhitungan Importance and Perfomance Analysis (IPA) akan menghasilkan skor ratarata tingkat kepentingan dan tingkat kepercayaan masing-masing atribut akan menentukan posisi atribut dan urutan prioritas atribut dengan menggunakan diagram kartesius yang nantinya dibagi dalam empat kuadran.

$$
\begin{array}{cc}
a=\frac{\sum \overline{\mathrm{Xi}}}{k} & b=\frac{\sum \overline{\mathrm{Yi}}}{k} \\
a=\frac{61.36}{20} & b=\frac{61.28}{20} \\
a=3.068 & b=3.064
\end{array}
$$

Nilai rata-rata tingkat kepentingan dan tingkat kinerja keseluruhan atribut digunakan untuk garis tengah dalam diagram kartesius. Nilai rata-rata tingkat kepentingan keseluruhan atribut digunakan untuk 
garis tengah sumbu (Y) yaitu 3.068 dan nilai rata-rata tingkat kinerja keseluruhan atribut digunakan untuk garis tengah sumbu $(\mathrm{X})$ yaitu 3.064 .

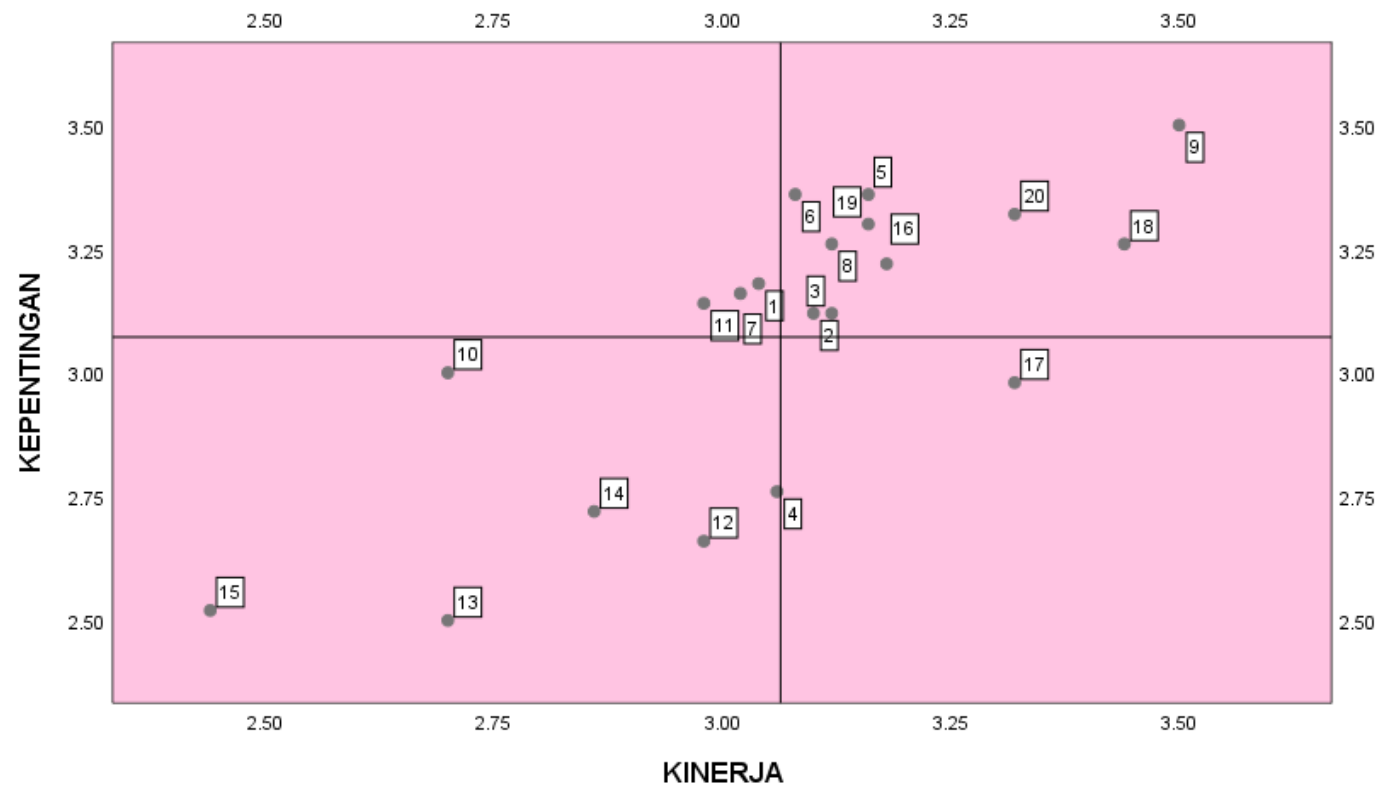

Gambar 2. Diagram Kartesius Importance and Perfomance Analysis (IPA)

\section{a. Kuadran I (Prioritas Utama)}

Atribut-atribut beras yang termasuk ke dalam kuadran I memiliki tingkat kepentingan yang tinggi tetapi dengan kinerja yang rendah (di bawah rata-rata). Hal ini berarti atribut-atribut beras pada kuadran I perlu diperhatikan secara khusus untuk dapat ditingkatkan kinerjanya agar kepuasan konsumen dapat meningkat.

\section{Bentuk beras}

Bentuk beras merupakan bentuk biji pada beras. Bentuk beras secara umum digolongkan atas butir sangat lonjong $(>7 \mathrm{~mm})$, lonjong $(6-6,9 \mathrm{~mm})$, agak bulat $(5-5,9 \mathrm{~mm})$ dan bulat $(<5 \mathrm{~mm})$. Atribut bentuk beras dinilai penting oleh responden dan atribut ini menghasilkan tingkat kepentingan dengan nilai 3.18 dan tingkat kinerja dengan nilai 3.04. Kinerja atribut bentuk beras harus diperhatikan secara khusus sehingga mampu meningkatkan kepuasan konsumen.

\section{Aroma nasi}

Atribut aroma nasi memiliki tingkat kepentingan yang dinilai 3.12 dan tingkat kinerja yang dinilai 3.1 oleh responden. Artinya, aroma beras setelah dimasak menjadi nasi belum memberikan kepuasan bagi konsumen. Aroma nasi dipengaruhi oleh varietas padinya, sehingga tidak dapat dibuat oleh produsen. Aroma yang bisa dijaga adalah menghindari beras dari bau tengik dan apek. Hal ini sangat 
berkaitan dengan proses penyimpanan, baik penyimpanan oleh produsen ataupun penyimpanan oleh pedagang.

\section{Kemasan memiliki merek}

Atribut kemasan memiliki merek menghasilkan tingkat kepentingan dengan nilai 3.14 dan tingkat kinerja dengan nilai 2.98. Kemasan beras memiliki merek dinilai penting bagi konsumen, namun kinerja yang masih rendah menjadikan atribut ini pada kuadran I. Pabrik pengemas beras dapat memberikan merek dagang di kemasan beras agar kepuasan konsumen dapat meningkat.

\section{b. Kuadran II (Pertahankan Prestasi)}

Atribut-atribut beras yang termasuk dalam kuadran II dinilai penting dan telah memiliki kinerja yang baik dan perlu dipertahankan.

\section{Warna alami (putih)}

Atribut warna alami (putih) pada beras menjadi salah satu ketertarikan konsumen pada saat membeli beras untuk dikonsumsi. Atribut warna alami (putih) memiliki tingkat kepentingan yang dinilai 3.12 dan tingkat kinerja yang dinilai 3.1. Hal ini menunjukkan secara keseluruhan atribut warna alami (putih) telah memberikan kepuasan kepada konsumen.

Warna alami (putih) pada beras dipengaruhi oleh tingkat penyosohan beras. Rahmat (2010) menyatakan bahwa makin tinggi derajat penyosohan yang dilakukan, makin putih warna beras giling yang dihasilkan, karena banyak lapisan aleuron yang hilang. Lapisan aleuron mengandung zat gizi yang terkandung pada beras. Semakin hilang lapisan aleuron semakin berkurang zat gizi beras. Selain dari proses penggilingan, jangka waktu penyimpanan beras juga mempengaruhi wana alami (putih) beras (Zahrotun, 2015). Semakin lama beras disimpan, beras dapat berubah warna. Hal ini menjadi salah satu alasan konsumen menilai warna alami (putih) pada beras tidak terlalu penting.

\section{Keutuhan beras}

Menurut Moehyi (1992) bahwa butiran-butiran biji beras tampak utuh atau tidak banyak yang patah merupakan patokan yang dapat digunakan dalam memilih beras yang baik. Atribut keutuhan beras memiliki tingkat kepentingan yang dinilai 3.04 dan tingkat kinerja yang dinilai 3.1. Meskipun nilai tingkat kepentingan dari atribut keutuhan beras yang rendah, kinerja dari keutuhan beras relatif tinggi. Keutuhan beras dipengaruhi oleh beberapa faktor, misalnya cuaca saat pemanenan beras dan sistem penjemuran yang dilakukan oleh petani. Hal ini menunjukkan bahwa konsumen merasa puas dengan kinerja dari atribut keutuhan beras. 


\section{Bersih dari benda selain beras}

Beras yang tercampur dengan benda asing sering terjadi, baik untuk beras dalam kemasan maupun beras tanpa kemasan. Beras dapat tercampur atau terkontaminasi dengan batu, gabah, dan lainnya. Atribut kebersihan dari benda selain beras memiliki tingkat kepentingan yang tinggi dengan nilai 3.36 dan tingkat kinerja yang dinilai 3.16. Dengan demikian, atribut ini belum memberikan kepuasan yang maksimal bagi konsumen. Berdasarkan pada nilai tingkat kepentingan dan tingkat kinerja yang didapatkan untuk atribut bersih dari benda selain beras, produsen diharapkan dapat meningkatkan kebersihan beras sehingga kepuasan konsumen akan meningkat.

Kebersihan benda selain beras dapat dilihat dari cara memanen beras dan cara penjemuran beras. Proses pemanenan dan penjemuran dapat menyebabkan beras terkontaminasi bendabenda asing jika tidak dijaga kebersihannya.

\section{Kepulenan}

Nasi pulen adalah nasi yang cukup lunak walaupun sudah dingin, lengket tetapi kelengketannya tidak sampai seperti ketan, antar biji lebih berlekatan satu sama lain dan mengkilat (Haryadi, 2006). Atribut kepulenan memiliki tingkat kepentingan yang tinggi dengan nilai 3.36 dan tingkat kinerja yang dinilai 3.08. Hal ini menunjukkan jika atribut kepulenan belum memberikan kepuasan yang maksimal bagi responden. Atribut kepulenan yang berada pada kuadran II mengharuskan produsen untuk mampu meningkatkan kinerjanya agar kepulenen beras dapat meningkatkan kepuasan bagi konsumen

\section{Daya tahan beras untuk disimpan}

Daya tahan beras mencakup lama ketahanan produk yang menunjukkan layak tidaknya dikonsumsi setelah dibeli dan disimpan dalam waktu tertentu. Atribut daya tahan beras untuk disimpan memiliki tingkat kepentingan yang dinilai 3.26 dan tingkat kinerja yang dinilai 3.16. Dari nilai tersebut dapat diartikan daya tahan beras untuk disimpan merupakan atribut yang penting dan dinilai belum mampu memberikan jaminan terhadap perubahan warna dan aroma beras. Sehingga perlu dipertahankan dan ditingkatkan kinerja daya tahan beras untuk disimpan agar dapat memberikan kepuasan kepada konsumen.

\section{Hama kutu}

Hama kutu yang bisa hidup di dalam beras menjadi salah satu faktor kebersihan beras. Atribut hama kutu memiliki tingkat kepentingan yang dinilai paling tinggi oleh responden yaitu 3.5 dan tingkat kinerja yang dinilai paling tinggi oleh responden yaitu 3.5. Hal ini menunjukkan jika atribut hama kutu dinilai sangat penting oleh konsumen dan telah memuaskan dengan tidak adanya hama kutu dalam beras dilihat dari tingkat kinerja yang dinilai tinggi. Oleh karena itu, 
atribut hama kutu perlu dipertahankan kinerjanya agar atribut ini tetap memberikan kepuasan yang maksimal bagi konsumen.

Sirkulasi beras di Pasar Krian sangat cepat. Mayoritas supplier beras akan mengirim ke pedagang beras di Pasar Krian dalam waktu 2 hari sekali. Ada pula supplier yang mengirim setiap hari, dan 3 hari sekali. Sirkulasi beras yang cepat menjadi salah satu faktor tidak adanya hama kutu dalam beras yang dijual di Pasar Krian. Beras yang telah lama disimpan beresiko memiliki hama kutu, namun beras yang telah dibeli konsumen akan langsung dimasak dalam waktu dekat. Sehingga kecil kemungkinan beras akan memiliki hama kutu.

\section{Kemudahan diolah}

Atribut kemudahan diolah memiliki tingkat kepentingan yang dinilai 3.22 dan tingkat kinerja yang dinilai 3.18. Hal ini menunjukkan jika atribut kemudahan beras untuk diolah juga dinilai penting oleh responden dan telah memuaskan konsumen dilihat dari tingkat kinerjanya yang dinilai baik.

\section{Harga beras}

Harga merupakan salah satu atribut yang paling dipertimbangkan konsumen pada saat membeli produk. Berdasarkan hasil perhitungan, atribut harga beras dinilai penting oleh konsumen dengan tingkat kepentingan 3.26 dan tingkat kinerja yang dinilai 3.44. Hal ini menunjukkan harga beras dinilai penting oleh konsumen dan telah memberikan kepuasan bagi konsumen dilihat dari tingkat kinerja yang dinilai baik. Pada umumnya, harga beras merupakan faktor utama yang sangat diperhatikan sebelum konsumen memutuskan untuk membeli beras. Hasil kuesioner menunjukkan bahwa seluruh responden menyatakan bahwa harga beras di Pasar Krian adalah terjangkau. Hal ini menunjukkan bahwa konsumen membeli beras yang harganya sesuai dengan pendapatan masing-masing konsumen.

\section{Mengenyangkan}

Atribut mengenyangkan memiliki tingkat kepentingan yang dinilai 3.3 dan tingkat kinerja yang dinilai 3.16. Hal ini menunjukkan bahwa atribut mengenyangkan dinilai penting dan telah memuaskan konsumen dilihat dari tingkat kinerjanya yang dinilai baik. Atribut ini menunjukkan jika konsumen memilih beras karena dianggap lebih mengenyangkan daripada sumber karbohidrat lainnya.

\section{Kebiasaan mengonsumsi}

Atribut kebiasaan mengonsumsi memiliki tingkat kepentingan yang dinilai 3.32 dengan tingkat kinerja yang dinilai 3.32. Hal ini menunjukkan atribut kebiasaan membeli dan mengonsumsi beras dinilai penting oleh konsumen dan telah memuaskan dilihat dari tingkat 
kinerjanya yang dinilai baik. Oleh karena itu, atribut ini perlu dipertahankan kinerjanya agar atribut kebiasaan mengonsumsi tetap memberikan kepuasan yang maksimal bagi konsumen dalam memenuhi kebutuhannya.

Sirkulasi beras di Pasar Krian sangat cepat. Beras di Pasar Krian habis terjual dalam waktu satu hingga tiga hari. Kebutuhan konsumen akan beras di Pasar Krian sangat tinggi. Hal ini menunjukkan bahwa konsumen belum bisa mengalihkan konsumsi alternatif pangan selain beras. Padahal, sumber karbohidrat bisa didapatkan dari bahan pangan lain, misalnya jagung, kentang, dan ketela. Artinya, program diversifikasi pangan sebagai salah satu upaya ketahanan pangan di Indonesia belum terimplementasi.

\section{c. Kuadran III (Prioritas Rendah)}

Atribut-atribut yang termasuk dalam kuadran III memiliki tingkat kepentingan yang relatif rendah dan tingkat kinerja yang relatif kurang. Atribut-atribut ini tidak terlalu diperhatikan dan dinilai tidak terlalu penting oleh konsumen.

\section{Beras pecah}

Beras pecah merupakan butir beras yang mempunyai butir patah yang ukurannya lebih kecil dari 6/10 tetapi lebih besar dari 2/10 bagian butir beras utuh. Atribut ini memiliki tingkat kepentingan yang dinilai 2.76 dan tingkat kinerja yang dinilai 3.18. Hal ini menunjukkan adanya beras pecah dianggap kurang penting dan kurang diperhatikan.

\section{Jenis/varietas beras}

Atribut jenis atau varietas beras memiliki tingkat kepentingan yang dinilai 3 dan tingkat kinerja yang dinilai 2.7. Hal tersebut menunjukkan atribut jenis atau varietas beras dinilai kurang penting dan kurang diperhatikan oleh konsumen.

\section{Plastik 5 kg}

Atribut plastik $5 \mathrm{~kg}$ memiliki tingkat kepentingan yang dinilai 2.66 dan tingkat kinerja yang dinilai 2.98. Kemasan plastik ukuran $5 \mathrm{~kg}$ dianggap kurang penting dan juga tidak terlalu diperhatikan oleh konsumen. Nilai kinerja kemasan plastik $5 \mathrm{~kg}$ yang juga relatif rendah menjadikan atribut ini berada pada kuadran III.

\section{Karung 10 kg}

Atribut karung $10 \mathrm{~kg}$ memiliki tingkat kepentingan yang dinilai 2.5 dan tingkat kinerja yang dinilai 2.7. Kemasan karung $10 \mathrm{~kg}$ juga dianggap kurang penting dan tidak terlalu diperhatikan oleh konsumen. Nilai kinerja kemasan plastik $5 \mathrm{~kg}$ yang juga relatif rendah menjadikan atribut ini berada pada kuadran III. 


\section{Karung $>10 \mathrm{~kg}$}

Atribut karung di atas $10 \mathrm{~kg}$ memiliki tingkat kepentingan yang dinilai 2.72 dan tingkat kinerja yang dinilai 2.86. Kemasan karung di atas $10 \mathrm{~kg}$ dianggap tidak terlalu penting dan tidak terlalu diperhatikan oleh konsumen. Nilai kinerja kemasan plastik $5 \mathrm{~kg}$ yang juga relatif rendah menjadikan atribut ini berada pada kuadran III.

\section{Beras tanpa kemasan}

Atribut beras tanpa kemasan memiliki tingkat kepentingan yang dinilai 2.55 dan tingkat kinerja yang dinilai 2.44. Hal ini menunjukkan atribut beras tanpa kemasan dinilai tidak penting dan tidak diperhatikan oleh konsumen. Nilai tingkat kinerja atribut ini juga dinilai kurang baik.

Berdasarkan diagram kartesius di kuadran III, atribut ukuran kemasan beras tidak dipentingkan oleh konsumen dan tingkat kinerjanya juga rendah. Beberapa faktor yang menjadikan ukuran kemasan beras tidak penting dan tingkat kinerja rendah adalah kebutuhan setiap rumah tangga yang berbeda-beda, konsumen membeli sesuai dengan kemampuan finansialnya masing-masing, dan lebih mementingkan beras daripada kemasannya.

\section{d. Kuadran IV (Berlebihan)}

Atribut-atribut yang berada di kuadran IV termasuk ke dalam kriteria berlebihan. Artinya, penilaian konsumen terhadap atribut-atribut pada kuadran IV tidak penting karena memilik nilai rendah atau di bawah rata-rata tetapi tingkat kinerjanya sudah memuaskan konsumen.

\section{Mudah mendapatkan beras}

Atribut mudah mendapatkan beras memiliki tingkat kepentingan yang dinilai 2.98 dan tingkat kinerja yang dinilai 3.22. Artinya, atribut kemudahan mendapatkan beras sudah sesuai dengan keinginan konsumen walaupun dianggap kurang penting. Hal ini harus tetap dipertahankan agar kinerjanya tidak menurun. Bagi konsumen, untuk mendapatkan beras sudah dianggap mudah. Konsumen akan tetap membeli beras karena beras adalah kebutuhan pokok yang tidak bisa ditinggalkan dalam kehidupan sehari-hari.

Preferensi konsumen dapat dilihat dari atribut beras yang memiliki tingkat kepentingan paling tinggi. Berdasarkan hasil perhitungan analisis IPA (Importance and Perfomance Analysis), atribut beras yang memiliki tingkat kepentingan tertinggi adalah bebas hama kutu, bersih dari kotoran, dan pulen. Artinya, konsumen di Pasar Krian lebih menyukai beras yang bebas hama kutu, bersih dari kotoran, dan pulen. Mayoritas konsumen menyatakan bahwa beras yang dikonsumsi harus pulen karena nasi merupakan makanan pokok setiap kali makan. Meskipun harga beras yang pulen, bebas hama kutu, dan bersih dari kotoran relatif mahal, 
mayoritas konsumen tetap memilih beras yang pulen dan bersih karena sesuai dengan preferensinya.

\section{KESIMPULAN}

\section{Kesimpulan}

Atribut beras yang memiliki nilai tingkat kepentingan paling tinggi adalah bebas hama kutu, bersih dari kotoran, dan pulen. Sehingga, dapat disimpulkan bahwa preferensi konsumen beras di Pasar Krian adalah beras yang bebas dari hama kutu, bersih dari kotoran, dan pulen.

\section{Saran}

Prioritas perbaikan atribut berdasarkan atribut yang dinilai penting oleh konsumen, namun kinerjanya masih rendah adalah bentuk beras, aroma nasi, dan kemasan memiliki merek. Oleh karena itu, produsen beras dapat menanam jenis / varietas padi yang menghasilkan beras beraroma harum dan saat proses perontokan hingga penyimpanan beras untuk lebih berhati-hati agar bentuk beras tidak berubah dan tidak pecah. Bagi industri pengemasan beras agar beras yang dikemas sesuai dengan kualitasnya. Pemerintah seharusnya memberikan fasilitas advokasi, pendampingan, pengawasan, dan pembinaan kepada kualitas beras petani, sehingga petani bisa bekerja sama dengan industri pengemasan merek / label yang sesuai dengan kondisi beras tersebut.

\section{DAFTAR PUSTAKA}

Badan Pusat Statistik. 2018. Produksi Padi Menurut Kabupaten/Kota di Jawa Timur Tahun 2007 2017. https://jatim.bps.go.id/statictable/2018/10/31/1340/produksi-padi-menurut-kabupatenkota-di-jawa-timur-ton-2007-2017.html . Diakses Senin, 13 Januari 2020. 16.32

Haryadi. 2006. Teknologi Pengolahan Beras. Yogyakarta : Universitas Gadjah Mada Press.

Moehyi, S. 1992. Makanan Institusi dan Jasa Boga. Jakarta : PT Bharata.

Rahmat, R. 2010. Stabilisasi Mutu Beras Pecah Kulit melalui Penerapan Teknologi Penyimpanan Hermetik (terhubung berkala). http://www.majalahpangan.com/2010/04/stabilisasi-mutu-beraspecah-kulit-melalui-penerapan-teknologi-penyimpanan-hermetik/. Diakses Selasa, 17 Maret 2020.

Riyadi, D. M. 2002. Permasalahan dan Agenda Pengembangan Ketahanan Pangan:: Tekanan Penduduk, Degradasi Lingkungan dan Ketahanan Pangan. Pusat Dalam : Prosiding Studi Pembangunan dan Proyek Koordinasi Kelembagaan Ketahanan Pangan

Supranto. 2006. Pengukuran Tingkat Kepuasan Pelanggan. Jakarta : Rineka Cipta.

Sutrisno. 2007. Manajemen Keuangan. Yogyakarta : Ekonesia.

Zahrotun A., Marwanti S., Widadie F.. 2015. Analisis Preferensi Dan Kepuasan Konsumen Terhadap Atribut Mutu Beras Di Pasar Legi Surakarta. Jurnal Agrista Vol. 3 No. 3 : 371-380 